\title{
Ownership Structure and Bank Performance
}

\author{
A. Nora Azureen Abdul Rahman and B. Anis Farida Md Reja
}

\begin{abstract}
This paper provides evidence on the impact of different types of ownership structure on bank performance. Using secondary data, the empirical analysis of this study is confined to Malaysian commercial banks during the period of 2000 to 2011. Multiple regression with fixed effects model is used to test the research model. Testing on five categories of ownership structure such as insider, family, government, institutional and foreign ownership, the results suggest that bank performance varies with different types of ownership structure.
\end{abstract}

Index Terms-Bank, ownership structure, roe, roa.

\section{INTRODUCTION}

The relation between ownership structure and performance has been the subject of continuous debate since the original paper of [1]. Concentrated ownership structure is viewed as reducing the agency problem between shareholders and managers resulting from the separation between ownership and control. Large equity ownerships in a firm are believed to induce shareholders to monitor the manager's activities, refute them from engaging in moral hazard behavior and ensure that the managers work towards maximization of the shareholders interest [2]. In the case of banking, [3] contends that concentrated ownership enhances banks' control and monitoring of its activity through a better flow of information. Large shareholders are more effective in exercising their rights, thus having more control over the management. The existence of large shareholders is also associated with high performance of the bank. [4] indicates that equity ownership by corporate blockholders is positively related to firm value while [5]-[8] find that there are strong positive relationships between ownership concentration and profitability.

However, contrary to the findings, concentrated ownership is also found to have a negative impact on performance [9]. Firms with high concentration of ownership are found to be more prone to financial distress and crisis. [10] relates the high concentration of ownership structure of Malaysian banks as one of the major factors that cause the banks to suffer severe financial distress in 1998. He argues that the existence of large shareholders with high authority to make decisions and control the management creates moral hazard behavior which in the long term affects the banks' performance. This is because large shareholders tend to behave in a self serving behavior by making decisions that would maximize their profits although the decisions might increase the banks' risks and jeopardize the banks' long term

Manuscript received November 5, 2013; revised January 7, 2014

The authors are with the Universiti Utara Malaysia, Kedah, Malaysia (e-mail: azureen@uum.edu.my, anis@uum.edu.my). performance and survival.

Nevertheless, [11]-[13] argue that the impact of concentrated ownership structure lies in the types or the identity of the ownership or shareholders. This is because different types of shareholders always have different priorities, preferences and objectives [6], [8] and [14] find that type of ownership structure determines firm performance. Differences in ownership structure have two obvious consequences which are (i), the controlling shareholders have both incentive and power to discipline the management and (ii), the controlling shareholders can create conditions for a new problem when their interests are not aligned with the interest of the minority shareholders [4].

Although studies addressing the issue of ownership structure and bank performance have increased rapidly in the past few years, but the theoretical and empirical evidences did not conclusively resolve the issue. Furthermore, most of the studies are centered on non-financial firms and developed countries and very limited study done on financial institutions and developing countries such as Malaysia. As developing countries are characterized with different characteristics such as high dependency on banks as source of funding, concentrated ownership structure, less expertise and skills, technology, management and compensation and wages, it creates concern whether the results of the studies on developed countries could be generalized or applicable to the developing countries. The situation thus, creates research gaps on the study of ownership structure and bank performance in developing countries. Hence, focusing on Malaysian banks, the aim of this paper is to investigate the impact of different types of ownership structure on bank performance. The organization of this paper is as follows; Section II reviews the literature and research focus; Section III, methodology used in the study; Section IV, findings and Section V, concludes the paper.

\section{LITERATURE REVIEW}

Recent studies on ownership structure suggest that dispersedly held corporations as described in the model of [1] are less commonly found in countries outside US and UK. Concentrated ownership structure is found to be more pronounced especially in the developing countries. [6] indicates that more than 40 percent of publicly traded firms in nine East Asian countries are controlled by family. [15] finds that about 80 percent of non-financial companies in Thailand are family owned, while [16] finds that majority of companies listed on Bombay Stock Exchange are controlled by families. [17] in their study of the largest ultimate owners of East Asian countries reports that the ownership structure of most Asian countries is highly concentrated with Malaysia 
scored the third highest percentage $(30.73 \%)$ behind Thailand (36.32\%) and Indonesia (34.51\%). [18] indicates that the Malaysian banking structure consists of domestic and foreign banks while [19] reports that the ownership structure of domestic Malaysian banks is concentrated into family, government and institutional ownership.

Further, [19] finds that ownership structure in Malaysian banks in 2002-2003 are highly dominated by family and government ownerships with shareholdings of up to 60.9 percent, and 64.4 percent respectively. They argue that the merger exercised of the domestic banking system in the year 2000 has no significant impact on the ownership structure of the domestic banking industry; concentrated ownership structure with large shareholdings continues to exist in the domestic banking institutions [19], [20] finds that government shareholdings in Malaysian banks for the year 2000-2003 is 40 percent. They indicate that Malaysia has the highest percentage of government controlled banks compared to Thailand (30\%), Republic of Korea (28\%) and Indonesia (26\%). Further, they also find that Malaysia has the highest percentage of family shareholding in banks which is 30 percent, followed by Thailand $(17 \%)$ and Indonesia $(9 \%)$.

Ref. [11] indicates that the different types of ownership structure have important implications for corporate governance and performance. While some ownership structure focuses more on personal interest or benefits of the largest shareholders, there is also ownership structure that is more concern for the long term survival of the banks. Hence, the objectives, interests and priorities of the large shareholders results in a different impact on bank performance. [8] argues that the value of a firm depends on the internal shareholder's shares or type of ownership structure, while [12] finds that the identity of large owners has significant effects to bank performance. Similarly, [14] and [6] find that the type of ownership structure determines firm performance. However, the studies on the impact of each type of ownership on firm performance provide mixed results and still unclear [21].

Ref. [22] finds that the existence of insider ownership in a firm increases the firm's performance. [23] in their study of firms in Japan finds a positive relationship between insider ownership and performance. Similarly, [24] in their study of UK firms, and [25] in his study of firms in Switzerland find that insider ownership has a positive relationship with firm performance. However, a study by [26] finds that insider ownership has an unambiguous negative effect on firm performance while [27] indicates that insider ownership boost risk taking strategies among managers.

A study by [28] on Standard \& Poors 500 firms finds that family-owned firms perform better than the non-family firms. They indicate that family ownership is an effective organizational structure as compared to the non-family-owned firms. [29] finds that firm's profitability is lower when the controlling family's ownership is lower. Other studies such as [30] and [31] conclude that family-controlled business perform better than the other type of businesses. However, a study by [13] finds that family-owned firms have lower performance and lower risks while [4] argues that due to the high concentration of wealth in the business and the concern for the family legacy, family-owned firms tend to display an excessive risk aversion and forego profitable expansion strategies.

As for the impact of government ownership to performance, [32] in their studies of ownership structure of 179 countries around the world finds that government-owned banks in developing countries have lower profitability and higher costs than their private counterparts. [14] finds that higher government ownership of firms in 1970 is associated with the slower subsequent financial development and lower economic growth while [7] finds that government-owned banks have less profits than the privately-owned banks in spite of their lower costs. Conversely, [13] finds that government-owned banks have high risk taking and high performance while [33] in their study of 11 transition countries finds that government-owned banks performs better than the domestic private banks. Further, [34] finds that government ownership has a positive relationship with performance. They noted that most investors are more confident to conduct business with government-owned firms as they believe that the government would assist the firm in the time of trouble.

Studying on institutional ownership, [35] argues that institutional ownership advances firm performance. [36] suggests that institutional ownership affects the relationship between ownership and firm value whereby increased in voting power and control enhances the firm performance. Further, studies which looked at the direct impact of institutional ownership on performance such as [37] and [38] find that institutional ownership is positively related to firm performance. In contrast, a study by [39] finds that institutionally-owned firms does not adopt the Code of Best Practice, have weak and even negative relationship with firm value. On the other hand, a study by [40] finds that there is no significant relationship between institutional ownership and firm performance.

On the relation between foreign ownership and bank performance, [41] argues that due to the advantages of foreign banks such as large capital, diversification, high expertise, superior ability to diversify risks and the ability to offer services to multinational clients, foreign banks perform better that the domestic banks. Similarly, [42] in their study on Argentina finds that foreign banks have better performance than the domestic banks. [43] finds that foreign-owned banks are the most cost-efficient and provide better service than other banks. However, a study by [44] finds that foreign banks in Pakistan are less effective at recovering impaired loans than the domestic banks. Sharing the view, [45] finds that a rise in foreign ownership negatively affects bank performance. In a related study, [46] indicates that foreign banks in developed countries are less profitable than the domestic banks but perform better than the domestic banks in developing countries.

\section{DATA AND METhODOLOGY}

\section{A. Data and Sample}

This study covers the entire population of commercial banks in Malaysia over the 2000-2011 period. All the banks 
in the study are locally incorporated and have commenced operations in Malaysia before the year 2000. Due to the merger and acquisition of the banking institutions in 1999 and merger exercised between banks during the study period (2000-2011), the commercial banks in Malaysia as at 2011 are left with 22 banks; 9 domestic banks and 13 foreign banks However, due to problems of data availability, one of the foreign banks (China Bank Limited) is dropped from this study. Thus, the final sample size of this study is 252 observations; data are collected from 9 domestic and 12 foreign banks. Accounting based measures are used in this study as most of the banking institutions in Malaysia are not listed on the share market. [48] indicates that the use of accounting data is common in banking studies. They point out that reported banking data are generally less problematic than data for most other industries due to the financial nature of the primary assets and liabilities, and the more uniform reporting requirements imposed by regulators. [49] finds that both the accounting and market information produce early warning signals of problem institutions.

As for the ownership data, this study uses data of the ultimate owner of the sample banks as stated in their annual report under 'Ultimate Holding Company' title. This is based on findings by [6], [17] and [50], who find that corporate ownership structure in Malaysia are associated with indirect / ultimate ownership. Therefore, data on direct or immediate ownership of Malaysian companies are insufficient or inappropriate for determining control [51]. In identifying the large shareholders, this study examines shareholders that own at least 5 percent of voting rights. This ratio is in accordance with the definition of substantial shareholders under Malaysia Securities Industry Act 1983. [15] contends that the choice of cut-off points should be based on economic or legal frameworks of the given country. The ratio used in this study however, is smaller compared to [14], who uses 10 percent and [17], who focuses on shareholders with 50 percent of direct voting rights. Nevertheless, [52] contends that an ownership position of 5 percent is sufficient to influence corporate outcomes.

The large shareholders are then separated into different types of ownership structure such as family ownership, government ownership, institutional ownership and foreign ownership. In classifying the ownership types, the family ownership data are collected based on the surname of the largest shareholder in the bank. A bank is categorized as government ownership if the largest shareholder is a government owned company (as listed in the Treasury Department of Malaysia); institutional ownership, the major shareholder in the bank is an institution, and foreign ownership, the major shareholder is a foreign company or the bank is a subsidiary of a foreign bank. Realizing the high existence of insider (board of directors who hold shares in the bank), this study also includes the 'insider' as one of the variable that might affects bank performance.

Data collected on the ownership structure of Malaysian banks over 2000-2011 period shows a highly concentrated ownership structure. The data demonstrate that most of Malaysian domestic banks are highly controlled by family; with most of them hold shares of more than 65 percent. The ownership structure of domestic Malaysian banks and its shareholdings over the 2000-2011 period is presented in Table I.

TABLE I: OWNERSHIP STRUCTURE AND SHAREHOLDINGS

\begin{tabular}{lll}
\hline Banks & Mean & Max \\
\hline Family owned & & \\
\hline AmBank & 0.38550 & 0.6900 \\
Hong Leong & 0.65257 & 0.7170 \\
Public Bank & 0.34542 & 0.3900 \\
RHB Bank & 0.35917 & 0.6500 \\
\hline Government owned & & \\
\hline Affin Bank Berhad & 0.47267 & 0.6210 \\
CIMB Bank Berhad & 0.41650 & 0.5230 \\
Maybank Berhad & 0.59525 & 0.6270 \\
\hline Institutional owned & & \\
\hline Alliance Bank Berhad & 0.30058 & 0.3640 \\
EON Bank Berhad & 0.24336 & 0.3370 \\
\hline
\end{tabular}

Source: Annual reports of individual bank.

\section{B. Panel Data Methodology}

Using panel data, heteroscedasticity and autocorrelation are the two common problems that normally exist in panel data analysis. Thus, Breush-Pagan-Godfrey test and Lagrange Multiplier test are used to identify these problems respectively. The heteroscedasticity and autocorrelation problem are then resolve using White's heteroscedsticity test and first difference method. As data of this study deviate from the normality assumption, regression analysis is conducted by using GLS estimation. This method is more appropriate as it helps to reduce the normality issue in the model; GLS method acts as a transformed model of OLS and is more appropriate than OLS in the case of non-normal data. Testing on the best panel data model for this study, Hausman test shows that fixed effects model outperformed random effects model for both ROE and ROA.

\section{Hypotheses Tested}

Based on agency theory and previous studies, the relationship between ownership structure and bank performance is hypothesized as follows:

- $\mathrm{H}_{1}$ : There is a positive relationship between INSIDER and bank performance

- $\mathrm{H}_{2}$ : There is a negative relationship between FAMOWN and bank performance

- $\mathrm{H}_{3}$ : There is a negative relationship between GOVOWN and bank performance

- $\mathrm{H}_{4}$ : There is a positive relationship between INSTOWN and bank performance

- $\mathrm{H}_{5}$ : There is a positive relationship between FOROWN and bank performance

\section{Empirical Model}

The following econometric model is used to test the hypotheses of the study.

$$
\begin{aligned}
\mathrm{BP}= & \alpha_{0}+\beta_{1} \text { INSIDER }_{\mathrm{it}}+\beta_{2} \text { FAMOWN }_{\mathrm{it}}+ \\
& \beta_{3} \text { GOVOWN }_{\mathrm{it}}+\beta_{4} \text { INSTOWN }_{\mathrm{it}}+\beta_{5} \text { FOROWN }_{\mathrm{it}}
\end{aligned}
$$

$\mathrm{BP}$ is bank performance and measured by return on equity (ROE) and return on assets (ROA). Ownership variables, which are insider ownership (INSIDER), family ownership (FMOWN), government ownership (GVOWN), institutional 
ownership (INSTOWN) and foreign ownership (FOROWN) are measured by total number of shares held / total number of shares in the bank.

\section{FINDINGS}

\section{A. Descriptive Statistics}

Table II presents the distribution of each variable for the total sample of 252 observations over the 2000 to 2011 period.

TABLE II: DESCRIPTIVE STATISTICS

\begin{tabular}{lllc}
\hline Variables & Mean & Std. dev & Max \\
\hline ROE & 0.3238 & 0.1671 & 0.8610 \\
ROA & 0.0289 & 0.0106 & 0.0849 \\
INSIDER & 0.1916 & 0.3369 & 0.9650 \\
FAMOWN & 0.0937 & 0.2138 & 0.7830 \\
GOVOWN & 0.1130 & 0.2024 & 0.8240 \\
INSTOWN & 0.0580 & 0.1307 & 0.8640 \\
FOROWN & 0.5787 & 0.4889 & 1.0000 \\
\hline
\end{tabular}

Table II shows that foreign-owned banks hold an average of 58 (0.5787) percent of shares in the Malaysian banks, which is much higher than other types of ownership structure. The large percentage is due to the large number of foreign banks in Malaysia (12 banks) as compared to the local banks (9 banks). As for the domestic banks, government holds the largest shares $(11 \%)$ followed by family-owned banks $(9 \%)$ and institutional-owned banks (6\%). Insider ownership is 19 percent, which indicates a high insider ownership in Malaysian banks. [53] indicates that insider ownership of more than 15 percent is considered as high and insider tends to align their interest with those of the shareholders in a high insider ownership, which is between 15 percent to 25 percent.

\section{B. Regression Results}

Considering the normality, heteroscedasticity and autocorrelation problems, as well as the hausman test result for panel data analysis, the regression results of this study is run by using GLS estimation with fixed effects model, White's heteroscedsticity test and first difference method. Using ROE and ROA as measures for bank performance, the regression results of the relationship between ownership structure and bank performance is presented in Table III.

TABLE III: OWNERSHIP STRUCTURE AND BANK PERFORMANCE

\begin{tabular}{lcc}
\hline Variables & ROE & ROA \\
\hline INSIDER & -0.1356 & -0.0064 \\
FAMOWN & $(-2.7389)^{* *}$ & $(-2.1300)^{*}$ \\
& -0.0817 & -0.0204 \\
GOVOWN & $(-0.5845)$ & $(-1.7708)$ \\
& -0.1084 & -0.0174 \\
INSTOWN & $(-2.5478)^{* *}$ & $(-2.1312)^{*}$ \\
& 0.0091 & -0.0016 \\
FOROWN & $(2.3881)^{* *}$ & $(-0.7172)$ \\
& -0.6508 & -0.0464 \\
AR $(1)$ & $(-0.5579)$ & $(-0.7260)$ \\
& 0.28217 & 0.3594 \\
$R^{2}$ & $(6.5948)^{* *}$ & $(7.0832)^{* *}$ \\
Adjusted $R^{2}$ & 0.7309 & 0.4490 \\
$F$-statistics & 0.6966 & 0.3787 \\
Sig $F$ statistics & 55.034 & 48.804 \\
$N$ & 0.0000 & 0.0000 \\
\hline Note: $*$ significance at $p<0.05 ; * *$ significance at $p<0.01$. & 231 \\
\hline
\end{tabular}

The results show that insider, government and institutional ownership are significant in explaining differences in the banks' ROE, while only insider and government ownership is significant to ROA. However, only the result of government ownership (for both ROE and ROA) is consistent with the hypothesis which indicates that high level of government ownership decrease bank performance. The results on the impact of government ownership on bank performance support the findings of previous research such as [7], [14], [32]. Sharing the view is [9], who points out that government-owned banks have poor long-term performance and [51], who finds that government-owned enterprises have negative effects on profitability, productivity, and investment in India. The result of this study is also consistent with [52] in his study of Malaysian banks, which finds that government-owned banks are less efficient than the privately-owned banks.

Although found significant in explaining changes in the bank performance, the results of insider ownership (for both performance measures) are inconsistent with the hypothesis. The different results of insider ownership than hypothesized indicate that 19 percent of insider ownership in Malaysian banks is not sufficient to induce insiders to align their interests to the interests of the banks' shareholders; in this case, to increase bank performance. [50] indicates that the higher the insider ownership, the more align is the interest of an insider with the shareholders while at a low level of ownership, insider tends to behave in a risk- averse manner in order to protect their own benefits.

As for institutional ownership, although the result is significant to ROE but it is not significant when ROA is used as a bank performance measure. Hence, the effects of institutional ownership on bank performance of Malaysian banks cannot be concluded. Surprisingly, the results on the impact of family and foreign ownership are insignificant to the banks' performance. The results imply that ownership structure does not explain changes in performance of family-owned banks as well as for the foreign banks in Malaysia during the study period.

\section{CONCLUSION}

Overall, the findings on Malaysian banks provide evidence that different types of ownership structure present different impact to the bank performance. The results show that insider ownership and government ownership have significant impact to changes in bank performance. However, the inconsistent results of insider ownership with the hypothesis implies that the existing shares held by insider is not sufficient to align the interest of the insider with those of the managers and thus, deter them to work towards maximizing the shareholders' interests or increase the banks' performance. The effects of institutional ownership to bank performance cannot be concluded as the results show that institutional ownership is only significant to ROE but insignificant to ROA. Meanwhile, the insignificant results of family ownership and foreign ownership suggest that both types of ownership structure do not have significant impacts to the bank performance. 


\section{REFERENCES}

[1] A. A. Berle and G. C. Means, "The modern corporation and private property," Macmillan, New York, 1932.

[2] M. Belkhir, "Additional evidence on insider ownership and bank risk taking," Banques and Marche, vol. 78, pp. 34-43, 2005.

[3] M. S. Ungureanu, "Banks: regulation and corporate governance framework," Journal of Ownership and Control, vol. 5, no. 2. pp. 1-19, 2008.

[4] R. Morck, M. Nakamura, and A. Shivdasani, "Bank, ownership structure and firm value in Japan," Journal of Business, vol. 73, pp. 539-567, 2000.

[5] R. A. Cole and H. Mehran, "The Effect of changes in ownership structure on performance: evidence from the trift industry," Journal of Financial Economics, vol. 50, pp. 291-317, 1998.

[6] S. Claessens, S. Djankov, and L. H. P. Lang, "The separation of ownership and control in East Asian corporations," Journal of Financial Economics, vol. 58, pp. 81-112, 2000.

[7] G. Iannota, G. Nocera, and A. Sironi, "Ownership structure, risk and performance in the European banking industry," Journal of Banking and Finance, vol. 31, pp. 2127-2149, 2007.

[8] V. O. Ongore, "The relationship between ownership structure and firm performance: An empirical analysis of listed companies in Kenya,' African Journal of Business Management, vol. 5, no. 6, pp. 2120-2128, 2011.

[9] A. N. Berger, G. R. G. Clarke, R. Cull, L. Klapper, and G. F. Udell, "Corporate governance and bank performance: A joint analysis of the static, selection and dynamic effects of domestic, foreign and state ownership," Journal of Banking and Finance, vol. 29. pp. 2179-2221, 2005.

[10] R. Thillainathan, "Corporate governance and restructuring in Malaysia, a review of markets, mechanisms, agents and the legal infrastructure,' paper prepared for the joint World Bank/OECD Survey of Corporate Governance arrangements in a selected number of Asian Countries, pp. 1-66, 1999.

[11] A. Shleifer and R. Vishny, "A survey of corporate governance," The Journal of Finance, vol. LII, pp. 737-783, 1997.

[12] S. Thomsen and T. Pedersen, "Ownership structure and economic performance in the largest European companies," Strategic Management Journal, vol. 21, no. 6, pp. 689-705, 2000.

[13] G. Gursoy and K. Aydogan, "Equity ownership structure, risk taking, and performance," Emerging Markets Finance and Trade, vol. 6, no. 38, pp. 6-25, 2002.

[14] R. L. Porta, F. Silanes, and A. Shleifer, "Government ownership of banks," The Journal of Finance, vol. LVII, pp. 265-301, 2002.

[15] Y. Wiwattanakantang, "Controlling shareholders and corporate value: Evidence from Thailand," Pacific-Basin Finance Journal, vol. 9, pp. 323-362, 2001.

[16] T. Khanna and K. Palepu, "Emerging market business groups, foreign investors and corporate governance," National Bureau of Economic Research, Working paper 6955, pp. 1-31, 1999.

[17] J. P. H. Fan and J. T. Wong, "Corporate ownership structure and the informativeness of accounting earnings in East Asia," Journal of Accounting and Economic, vol. 33, pp. 401-425, 2002.

[18] E. Detragiache and P. Gupta, "Foreign banks in emerging markets crises: Evidence from Malaysia," Journal of Financial Stability, vol. 2 , pp. 217-242, 2006.

[19] L. C. Soon and P. T. Koh, "Corporate governance of banks in Malaysia,” Banker's Journal Malaysia, vol. 131, pp. 10-48, 2007.

[20] J. P. H. Fan and Y. Wiwatanakantang, "Bank ownership and governance quality in four post-crisis Asian Economies," Asian Development Bank (ADB) Institute, pp. 1-27, 2005.

[21] M. M. Cornett, A. J. Marcus, A. Saunders, and H. Tehranian, "The impact of institutional ownership on corporate operating performance,' Journal of Banking and Finance, vol. 31, pp. 1771-1794, 2007.

[22] B. Moldenhauer. (2006). Insider ownership, corporate performance and the German entrepreneurial index-Practical and Academic Evidence from Germany. CEFS. [Online]. pp. 1-45. Available http://www.eurocapitalmarkets.org/files/Moldenhauer.pdf

[23] C. R. Chen, W. Guo, and V. Mande, "Managerial ownership and firm valuation: Evidence from Japanese firms," Pacific-Basin Finance Journal, vol. 11, no. 3, pp. 267-283, 2003.

[24] J. R. Davies, D. Hillier, and P. McColgan, "Ownership structure, managerial behavior and corporate value," Journal of Corporate Finance, vol. 11, no. 4, pp. 645-660, 2005.

[25] S. Beiner, W. Drobetz, M. Schmid, and Zimmermann. (2005). An integrated framework of corporate governance and firm valuation as in B. Moldenhauer. (2006). Insider Ownership, Corporate Performance and the German Entrepreneurial Index-Practical and Academic
Evidence from Germany. [Online]. Available: http://www.eurocapitalmarkets.org

[26] K. Gugler, D. C. Mueller, and B. Yurtoglu, "Insider ownership, ownership concentration and investment performance: An international comparison," Journal of Corporate Finance, vol. 14, no. 5, pp. 688-705, 2008.

[27] R. J. Sullivan and K. R. Spong, "Manager wealth concentration, ownership structure and risk in commercial banks," Journal of Financial Intermediation, vol. 16, no. 2, pp. 229-248, 2007.

[28] R. C. Anderson and D. M. Reeb, "Founding family ownership, corporate diversification and firm leverage," Journal of Law and Economics, vol. 46, no. 2, pp. 653-684, 2003

[29] G. Pinteris, "Agency costs, ownership structure and performance in Argentine banking," paper presented in Southern Finance Association, Argentine, 2002

[30] B. Maury and A. Pajuste, "Multiple Large shareholders and firm value," Journal of Banking and Finance, vol. 29, pp. 1813-1834, 2005

[31] B. Villalonga and R. Amit, "How do family ownership control and management affect firm value?" Journal of Financial Economics, vol. 80 , no. 2 , pp. 385-417, 2006.

[32] A. Micco, U. Panizza, and M. Yanez, "Bank ownership and performance. Does politics matter?" Journal of Banking and Finance, vol. 31, pp. 219-241, 2007

[33] J. P. Bonin, I. Hasan, and P. Wachtel, "Bank performance, efficiency and ownership in transition countries," Journal of Banking and Finance, vol. 29, pp. 31-53, 2005.

[34] A. F. Najid and R. A. Rahman, "Government ownership and performance of Malaysian government-linked companies," International Research Journal of Finance and Economics, vol. 61. pp. 42-56, 2011.

[35] C. J. Hartzell and L. T. Starks, "Institutional investors and executive compensation," The Journal of Finance, vol. LVIII, no. 6, pp. 2351-2374, 2003.

[36] B. Maury, "Family ownership and firm performance: Empirical evidence from Western European Corporations," Journal of Corporate Finance, vol. 12, pp. 321-341, 2006.

[37] M. Smith, "Shareholder activism by institutional investors. Evidence from CalPERS," Journal of Finance, vol. 51, pp. 227-252, 1996.

[38] D. D. Guercio and J. Hawkins, "The motivation and impact of pension fund activism,” Journal of Financial Economics, vol. 52, pp. 293-340, 1999.

[39] M. Faccio and M. A. Lasfer, "Institutional Shareholders and corporate governance: The case of UK pension funds," Working Paper, Center for Research on Pensions and Welfare Policies, vol. 11, no. 1, pp. 1-41, 2001.

[40] A. Agrawal and C. R. Knoeber, "Firm performance and mechanisms to control agency problems between managers and shareholders," Journal of Finance and Quantitative Analysis, vol. 31, no. 3, pp. 377-397, 1996.

[41] B. G. Dages, G. Linda, and D. Kinney, "Foreign and domestic bank participation in emerging markets: Lessons from Mexico and Argentina," Federal Reserve Bank of New York Economic Policy Review, pp. 17-36, 2000.

[42] A. Mian, "Foreign, private domestic and government banks: New evidence from emerging markets," Working Paper, University of Chicago, pp. 1-46, 2003.

[43] R. Lensink and I. Naaborg, "Does foreign ownership foster bank performance?" Applied Financial Economics, vol. 17, no. 11, pp. 881-885, 2007.

[44] K. Demirguc and H. Huizinga, "Determinants of commercial bank interest margins and profitability: Some international evidence," The World Bank Economic Review, vol. 13, no. 2, pp. 379-408, 1999.

[45] R. Rivard and C. Thomas, "The effect of interstate banking on large bank holding company profitability and risk," Journal of Economics and Business, vol. 49, pp. 61-76, 1997.

[46] R. H. Pettway and J. F. Sinkey, "Establishing on-site bank examination priorities: An early warning system using accounting and market information," The Journal of Finance, vol. XXXV, pp. 137-150, 1980.

[47] K. V. Lins, "Equity ownership and firm value in emerging market," Journal of Financial and Qualitative Analysis, vol. 36, pp. 159-184, 2003.

[48] I. Zuaini. "Corporate boards, ultimate ownership structure and corporate diversification: A study of public listed companies in Malaysia," Unpublished Doctoral dissertation, School of Management, University of South Hampton, 2004.

[49] H. Demsetz and K. Lehn, "The structure of corporate ownership: causes and consequences," Journal of Political Economy, vol. 93, vol. 6, pp. 1155-1177, 1985. 
[50] G. Gorton and R. Rosen, "Corporate control, portfolio choice and the decline of banking," The Journal of Finance, vol. 50, pp 1377-1420, 1995.

[51] N. Gupta, "Partial privatization and firm performance," Journal of Finance, vol. 60, pp. 987-1015, 2005.

[52] A. K. M. Zaini, "Ownership and efficiency in Malaysian banking," The Philippine Review of Economics, vol. XL, no. 2, pp. 91-101, 2003.

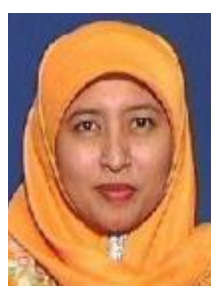

Nora Azureen Abdul Rahman was born in Kuala Lumpur, Malaysia. Her educational background is finance and banking and has obtained her $\mathrm{PhD}$ from Universiti Utara Malaysia, Malaysia in 2012. She is currently a senior lecturer in the Banking and Risk Management Department of School of Economics, Finance and Banking, College of Business, Universiti Utara Malaysia, Kedah, Malaysia. Her research focus is on banking in the areas of risks, corporate governance, moral hazard, capital regulation and performance. She has been very active in presenting research papers in conferences and has published in national and international proceedings and journals in the areas of banking. She is also actives in writing books and modules especially in the area of finance, banking and risks. Dr. Nora Azureen Abdul Rahman is currently an associate member of the Institute of Bankers Malaysia (IBBM), a professional body for banking and financial services industry in Malaysia.

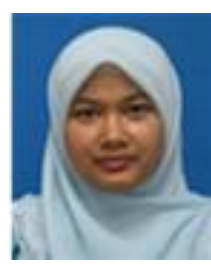

Anis Farida Md Rejab was born in Kedah, Malaysia. Her educational background is in banking area and has obtained her master's degree from Universiti Utara Malaysia, Malaysia in 2011. Currently she is preparing for her $\mathrm{PhD}$. She is currently a tutor at Banking and Risk Management Department of School of Economics, Finance and Banking, College of Business, Universiti Utara Malaysia, Kedah, Malaysia. Her areas of interest are corporate governance and merger and acquisition (M\&A). She had been awarded a Gold Medal Award by Institute of Bankers Malaysia (IBBM) in 2010 for her high achievement in her Master degree. 